\title{
Comparing Shear Bond Strength Of Auto-polymerized Soft Lining Materials to Acrylic Denture Base Using Different Surface Treatment and Denture Base Materials.
}

\author{
Wasmaa S. Mohammed
}

B.D.S., M.Sc. - Lecturer, Department of prosthodontics, College of Dentistry, Baghdad university. Zaiynab Salih

B.D.S., M.Sc. - Lecturer, Department of prosthodontics, College of Dentistry, Baghdad university. Abdalbasit A. Fatihallah

B.D.S., M.Sc., Ph.D. - Assistant Professor, Department of prosthodontics, College of Dentistry, Baghdad university.

\begin{abstract}
:
Background: Denture bearing tissue condition may be highly affected by stress applied from the occlusal force during function of mastication therefore the need for denture soft lining material application is necessary and testing the bond strength of this material to acrylic denture base is of some point of interest and need to be improved. The aim of the study is to test the shear bond strength of soft lining materials to the denture base after surface modifications and using different denture base materials. Materials and Methods: 120 samples included in the study to test the shear bond strength, sample grouped according to surface treatment of acrylic resin (Control without surface treatment, monomer surface treatment, Nd-Yag laser surface treatment $(10 \mathrm{~Hz}$ and 20 Watt) and $\mathrm{Nd}$-Yag laser surface treatment $(10 \mathrm{~Hz}$ and 40 Watt)) with different denture base materials used (High impact acrylic, Heat cured acrylic and light cured acrylic), the shear bond strength test was made by using universal testing machine with cross head speed $40 \mathrm{~mm} / \mathrm{min}$ the force required for soft lining material complete separation from the acrylic resin materials calculated. Statistical analysis made by SPSS software analysis using ANOVA Table with LSD multiple Comparison.

Results: the highest value of shear bond strength found in group with high impact acrylic and 2nd dose of laser treatment applied, while the lowest one found In a group of light cured acrylic when 1st dose of laser treatment used. the comparison among groups made by using ANOVA Table with LSD which revealed that there was a highly significant difference between all groups with different surface treatments except heat cured and light cured groups. A highly significant difference also found between 2nd dose of laser treatment and control, monomer and 1st dose of laser surface treatment when different materials used.

Conclusion: 2nd dose of laser surface treatment when $10 \mathrm{~Hz}$ and 40 Watt of $\mathrm{Nd}$-Yag Laser applied Show the highest value of shear bond strength in high impact acrylic group, while the lowest value was recorded in light cured acrylic with 1st does laser treatment. KEYWORDS:
\end{abstract}

Soft lining materials, denture base, Laser, Monomer. High impact acrylic, light cured acrylic.

CITE THIS ARTCLE:

Mohammed W,Salih Z, Fatihallah A.Comparing Shear Bond Strength Of Auto-polymerized Soft Lining Materials to Acrylic Denture Base Using Different Surface Treatment and Denture Base Materials. Iraqi Dent. J. 2016; 38(1):6-11. http://www.iraqidentaljournal.com

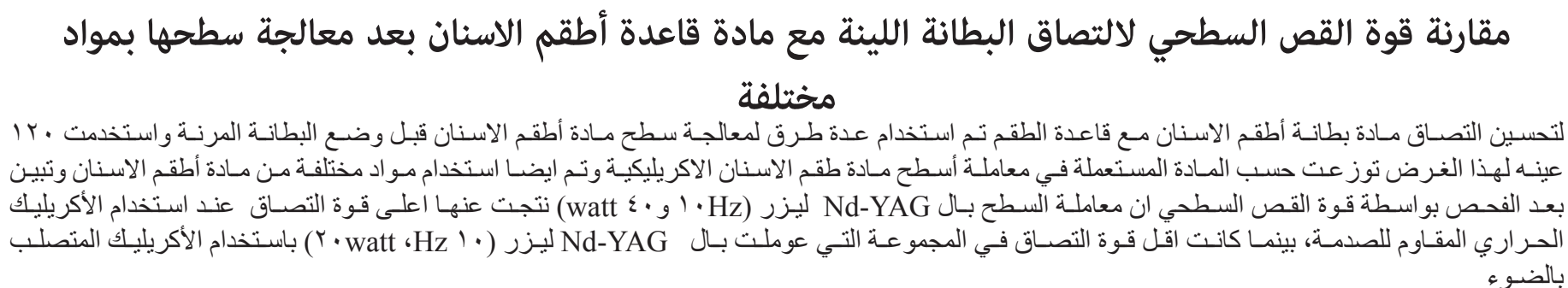

\section{INTRODUCTION:}

Although soft lining material was first used in 1961 widely in partial and complete dentures ${ }^{(1)}$, and should fulfill a list of requirements, but above of all it should bond in a satisfactory way with acrylic denture base; otherwise problems will arise like plaque accumulation, bacterial growth...etc ${ }^{(2-4)}$.

So many researchers suggested different methods for improving bond between soft liners and acrylic denture base like mechanical roughening by laser, monomer, or by sandblasting ${ }^{(5-7)}$.

Laser is an intense beam of light energy, it was first developed by Mainman in 1960, in its early invention laser was a technical breakthrough, but was a technology rather than purpose ${ }^{(8)}$.

Laser gets the approval from the FDA and was introduced to dentistry about 35 years ago, and since that, researches continues to expand in this field ${ }^{(9)}$, it becomes more common for caries removal, root canal treatment, remove periodontal disease, bleaching, disinfecting.

Laser light has the advantage of interacting with biological tissue because of its particular properties: (1) monochromaticity i.e. one color (2) coherence like waves have identical amplitude and frequency (3) collimation like laser rays are parallel and don't diverge (4) brightness ${ }^{(10)}$. 
There are many types of lasers such as ruby laser, He-Ne laser, Nd-YAG laser, Co2 laser, and Er-YAG laser, in this study Nd-YAG laser used, it was first used in 1990, and it is near the infrared wavelength of $1064 \mathrm{~nm}$. It works on contact and non-contact way, which both can be used depending on performed procedure ${ }^{(11)}$.

Because laser have the capacity to alter surface of material in a relatively easy and safe way ${ }^{(12)}$, it can be used to increase bonding between materials and make benefit to solve the drawback of soft liner and denture base.

The use of laser in these studies are still limited so the present study try to make a comparison between monomer and laser application using different denture base materials and find out what will come with best result to overcome the dilemma of soft liner detachment from acrylic denture base.

MATERIALS AND METHODS:

\section{Sample Grouping:}

120 samples were constructed, divided according to materials' used: (high impact/ Vertex), (heat cure, Triplex) and (light cure, Vertex LC), each group was further subdivided according to surface treatments; so that the total number of groups included in the study were twelve groups and they were summarized as follows:

a.Control without surface treatments (Heat Cured
Acrylic)

b.Control without surface treatments (High impact Acrylic)

c.Control without surface treatments (Light Cured Acrylic)

d. Monomer surface treatment (Heat Cured Acrylic)

e. Monomer surface treatment (High impact Acrylic)

f.Monomer surface treatment (Light Cured Acrylic)

g.Laser surface treatment $10 \mathrm{~Hz} 20 \mathrm{Watt}$ (Heat Cured Acrylic)

h.Laser surface treatment $10 \mathrm{~Hz} 20 \mathrm{Watt}$ (High impact Acrylic)

i.Laser surface treatment $10 \mathrm{~Hz} 20 \mathrm{Watt}$ (Light Cured Acrylic)

j.Laser surface treatment $10 \mathrm{~Hz} 40 \mathrm{Watt}$ (Heat Cured Acrylic)

k.Laser surface treatment $10 \mathrm{~Hz} 40$ Watt (High impact Acrylic)

1.Laser surface treatment $10 \mathrm{~Hz} 40$ Watt (Light Cured Acrylic)

\section{Sample preparation:}

\section{High impact and heat cured acrylic samples:-}

A metal mold used for shear bond strength sample construction, it measured $(75 \mathrm{~mm}, 25 \mathrm{~mm}$, $5 \mathrm{~mm}$ ) length, width and height respectively, with $3 \mathrm{~mm}$ depth and handle thickness of $13 \mathrm{~mm}^{(13)}$ to have a maximum clamping of samples with instron machine (Fig. 1).

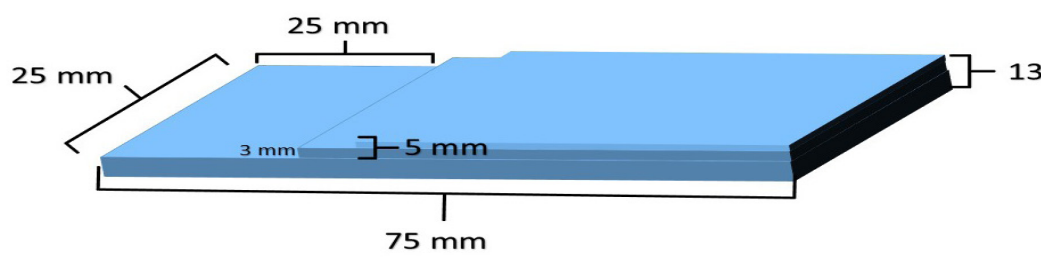

Fig. 1. Shear Bond Strength Specimen.

The samples constructions for high impact acrylic denture base materials were done by mixing of powder and liquid according to manufacturer's instruction $(\mathrm{P} / \mathrm{L}$ ratio $21 \mathrm{~g} / 10 \mathrm{ml})$ then a layer of separating media applied to the stone mold made from the metal templates and the dough acrylic mixture adapted to the stone mold, cured in water bath at $70{ }^{\circ} \mathrm{C}$ for 90 minutes, followed by $100{ }^{\circ} \mathrm{C}$ for $30 \mathrm{~min}$. according to manufacturer's instructions, then allowed for bench cooling. The same procedure undertaken for heat cured except curing cycle which run under $70{ }^{\circ} \mathrm{C}$ for half an hour followed by $100{ }^{\circ} \mathrm{C}$ for one hour according to manufacturer's instructions.

\section{Light cure samples:}

The material was packed in stone mold after application of separating media, pressed with fingers, then cured by light curing unit (Vertex Ecoligth box/ Holland) initially for $5 \mathrm{~min}$ and removed from the mold and cured again for $5 \mathrm{~min}$. The excess materials removed with sharp wax knife before curing.

\section{Surface treatment:}

a.Monomer Surface treatment: Samples were swabbed with a cotton dipped in monomer for $180 \mathrm{sec}$ before soft liner application.

b.Laser surface treatment: Nd-Yag laser was used to treat the surface of the acrylic which will bond to soft liner materials, the wavelength fixed to (1064 $\mathrm{nm}$ ), and the frequency fixed to $10 \mathrm{~Hz}$., while the power set to 20 and to 40 watt. The surface of the acrylic block divided into four lines, the distance between line and the other fixed to $6.35 \mathrm{~mm}$, each line divided into five parts equally and the laser 
strokes applied to these five points on each line, so that the total strokes applied to each specimen will be 20 strokes. The exposure time for each point will be set to $4 \mathrm{sec}$. The distance between the head of the laser device and the surface of the specimen fixed to $12 \mathrm{~mm}$ by using plastic cable tie ${ }^{(16)}$.

\section{Application of soft liner material to the samples:}

The soft lining material (mollosil/ chair side / Germany) was applied in the space between the two blocks of shear bond strength, one over the other in a space dimension of $25 \mathrm{~mm}, 25 \mathrm{~mm}, 3 \mathrm{~mm}$ (length, width and depth respectively); the reline material mixture applied by using spatula, the excess material was removed by sharp wax knife then samples placed under $200 \mathrm{~g}$ of load until complete set of material.

\section{Testing the samples:}

Testing was done by using Instron testing machine, the cross head speed $40 \mathrm{~mm} / \mathrm{min}$. and the soft lining material was separated from the acrylic plates ${ }^{(18)}$. The force required for this separation was calculated, the shear bond strength value of each sample was calculated by applying the following equation:

Shear Bond strength $=\mathrm{F}(\mathrm{N}) / \mathrm{A}\left(\mathrm{mm}^{2}\right)^{(19)}$.

$\mathrm{F}=$ force of failure $(\mathrm{N})$.

$\mathrm{A}=$ surface area of cross section $\left(\mathrm{mm}^{2}\right)$.

The data was analyzed by SPSS v. 21 statistical analysis software using ANOVA Table with LSD multiple comparison test.

\section{RESULTS}

As shown in Table 1, the highest mean of shear bond strength found in the group of high impact acrylic and when $2^{\text {nd }}$ dose of laser surface treatment applied, while the lowest value found in the group of light cured when $1^{\text {st }}$ dose of laser surface treatment applied.

Table 1: Descriptive Statistics for all groups.

\begin{tabular}{|c|c|c|c|c|c|c|c|c|c|}
\hline & \multirow{2}{*}{$N$} & \multicolumn{2}{|c|}{ Control } & \multicolumn{2}{|c|}{$\begin{array}{c}\text { Monomer Surface } \\
\text { Treatment }\end{array}$} & \multicolumn{2}{|c|}{$\begin{array}{c}1^{\text {st }} \text { Dose of Laser } \\
\text { Treatment }\end{array}$} & \multicolumn{2}{|c|}{$\begin{array}{c}2^{\text {nd }} \text { Dose of Laser } \\
\text { treatment }\end{array}$} \\
\hline & & $\begin{array}{c}\text { Mean }(\mathrm{N} / \\
\left.m m^{2}\right)\end{array}$ & SD & $\begin{array}{c}\text { Mean } \\
\left(N / m m^{2}\right)\end{array}$ & SD & $\begin{array}{c}\text { Mean } \\
\left(N / m m^{2}\right)\end{array}$ & SD & $\begin{array}{c}\text { Mean } \\
\left(N / m m^{2}\right)\end{array}$ & $S D$ \\
\hline Heat Cured & 10 & 0.747 & 0.029 & 0.756 & 0.018 & 0.746 & 0.037 & 0.838 & 0.023 \\
\hline High impact & 10 & 0.863 & 0.024 & 0.840 & 0.041 & 0.849 & 0.032 & 0.921 & 0.015 \\
\hline Light Cured & 10 & 0.745 & 0.036 & 0.765 & 0.012 & 0.740 & 0.037 & 0.856 & 0.019 \\
\hline
\end{tabular}

Inferential statistical analysis done by using ANOVA Table with LSD to compare both materials used in the study and different surface treatment of these materials, the results revealed that when comparing materials used in the study there is highly significance among all groups except when comparing heat cured and light cured materials using different surface treatments as shown in Table 2 and 3.

Table 2: ANOVA Table comparison for groups categorized according to method used for surface treatments.

\section{Control (Without Sur- face Treatment) \\ Monomer Surface Treatment}

$1^{\text {st }}$ Dose of Laser Treatment

$2^{\text {nd }}$ Dose of Laser treatment

\begin{tabular}{|c|}
\hline Sum of Squares \\
\hline 0.091 \\
0.025 \\
0.116 \\
0.042 \\
0.020 \\
0.062 \\
0.074 \\
0.035 \\
\hline 0.109 \\
0.038 \\
0.011 \\
0.049
\end{tabular}

\begin{tabular}{|c|c|c|c|}
\hline $\boldsymbol{d} \boldsymbol{f}$ & Mean Square & $\boldsymbol{F}$ & Sig. \\
\hline 2 & 0.045 & & \\
\hline 27 & 0.001 & 49.234 & H.S. \\
\hline 29 & & & \\
\hline 2 & 0.021 & & \\
\hline 27 & 0.001 & 28.379 & H.S. \\
\hline 29 & & & \\
\hline 2 & 0.037 & & \\
\hline 27 & 0.001 & 28.857 & H.S. \\
\hline 29 & & & \\
\hline 2 & 0.019 & & \\
\hline 27 & 0.000 & 47.732 & H.S. \\
\hline 29 & & & \\
\hline
\end{tabular}


Table 3: Multiple comparison Post hoc LSD test according to method used for surface treatments.

\begin{tabular}{|c|c|c|c|c|c|c|c|c|}
\hline & \multicolumn{2}{|c|}{ Control } & \multicolumn{2}{|c|}{ Monomer } & \multicolumn{2}{|c|}{$1^{s t}$ Dose } & \multicolumn{2}{|c|}{$2^{\text {nd }}$ Dose } \\
\hline & $\begin{array}{c}\text { Mean } \\
\text { Difference } \\
\text { (I-J) }\end{array}$ & Sig. & $\begin{array}{c}\text { Mean Dif- } \\
\text { ference }(I-J)\end{array}$ & Sig. & $\begin{array}{c}\text { Mean } \\
\text { Difference } \\
(I-J)\end{array}$ & Sig. & $\begin{array}{c}\text { Mean Dif- } \\
\text { ference (I-J) }\end{array}$ & Sig. \\
\hline $\begin{array}{l}\text { High impact- Heat } \\
\text { Cured }\end{array}$ & 0.1158 & H.S. & 0.0838 & H.S. & 0.1023 & H.S. & 0.0829 & H.S. \\
\hline $\begin{array}{c}\text { High Impact-Light } \\
\text { Cured }\end{array}$ & 0.1175 & H.S. & 0.0744 & H.S. & 0.1086 & H.S. & 0.0651 & H.S. \\
\hline $\begin{array}{c}\text { Heat Cured - Light } \\
\text { Cured }\end{array}$ & 0.0017 & 0.901 & -0.0094 & .447 & 0.0063 & 0.698 & -0.0178 & .057 \\
\hline
\end{tabular}

Table 4: ANOVA Table comparison for groups categorized according to material used

\begin{tabular}{|c|c|c|c|c|c|c|}
\hline & & $\begin{array}{l}\text { Sum of } \\
\text { Squares }\end{array}$ & $d f$ & $\begin{array}{l}\text { Mean } \\
\text { Square }\end{array}$ & $\boldsymbol{F}$ & Sig. \\
\hline \multirow{3}{*}{ High Impact } & Between Groups & 0.040 & 3 & 0.013 & \multirow{3}{*}{14.685} & \multirow{3}{*}{ H.S. } \\
\hline & Within Groups & 0.033 & 36 & 0.001 & & \\
\hline & Total & 0.073 & 39 & & & \\
\hline \multirow{3}{*}{ Heat Cured } & Between Groups & 0.059 & 3 & 0.020 & \multirow{3}{*}{24.973} & \multirow{3}{*}{ H.S. } \\
\hline & Within Groups & 0.028 & 36 & 0.001 & & \\
\hline & Total & 0.088 & 39 & & & \\
\hline \multirow{3}{*}{ Light Cured } & Between Groups & 0.087 & 3 & 0.029 & \multirow{3}{*}{35.903} & \multirow{3}{*}{ H.S. } \\
\hline & Within Groups & 0.029 & 36 & 0.001 & & \\
\hline & Total & 0.117 & 39 & & & \\
\hline
\end{tabular}

Table 5: Multiple comparison Post hoc LSD test according to material included in the study

\begin{tabular}{|c|c|c|c|c|c|c|}
\hline & \multicolumn{2}{|c|}{ High Impact } & \multicolumn{2}{|c|}{ Heat Cured } & \multicolumn{2}{|c|}{ Light Cured } \\
\hline & $\begin{array}{c}\text { Mean Dif- } \\
\text { ference }(I-J)\end{array}$ & Sig. & $\begin{array}{c}\text { Mean } \\
\text { Difference } \\
(I-J)\end{array}$ & Sig. & $\begin{array}{c}\text { Mean } \\
\text { Difference } \\
(I-J)\end{array}$ & Sig. \\
\hline Control- Monomer & 0.0232 & 0.094 & -0.0199 & 0.127 & -0.008 & 0.488 \\
\hline Control $=1^{\text {st }}$ Dose & 0.0142 & 0.300 & 0.0053 & 0.680 & 0.0007 & 0.956 \\
\hline Control- 2 ${ }^{\text {nd }}$ Dose & -0.0582 & H.S. & -0.1106 & H.S. & -0.0911 & H.S. \\
\hline Monomer- $1^{\text {st }}$ Dose & -0.009 & 0.509 & 0.0252 & 0.056 & 0.0095 & 0.455 \\
\hline Monomer- $2^{\text {nd }}$ Dose & -0.0814 & H.S. & -0.0907 & H.S. & -0.0823 & H.S. \\
\hline $1^{\text {st }}$ Dose- $2^{\text {nd }}$ Dose & -0.0724 & H.S. & -0.1159 & H.S. & -0.0918 & H.S. \\
\hline
\end{tabular}

\section{DISCUSSION}

An appropriate bond between denture base and soft lining material is a required demand, but unfortunately, all materials available are considered temporary compared to hard denture base, because it is associated with low physical and mechanical properties, it leads to bacterial and fungal aggregation, and poor bond to denture base material ${ }^{(20)}$.

Many researchers have been studied different methods and test to increase this bond, but there was a controversy about the effectiveness of surface treatment like monomer application, acetone, laser, aluminum oxide, making holes through acrylic, etc.... ${ }^{(2,3,12)}$, and the majority agreed with the fact that treating surface with abraded particles will decrease the bond ${ }^{(21)}$.

Fowler ${ }^{(22)}$ and Cantor et al ${ }^{(23)}$ pointed out that, tensile failure was not only due to tensile forces but also caused by shear forces occurred because of the high Poisson's ratio of silicone soft liner. So that 
testing the soft liner using shear bond test is believed to be a useful way to measure bond strength because of close simulation to clinical situations ${ }^{(24)}$.

There is a limited published papers studied the effect of laser on shear bond strength of different denture base and soft lining material; this study compare the effect of laser and monomer on three different types of denture base to improve bond with soft lining material.

The present study showed that the highest mean value of shear bond strength was for high impact denture base acrylic material when compared to heat cured and light cured denture base acrylic materials, this significant difference could be explained due to the fast raising in temperature during curing as a short curing cycle used, causing the production of many new radicals leading to more growing polymer chain, and more branching and cross linking ${ }^{(25)}$.

In this study, the effects of surface treatment with monomer on shear bond strength between soft liner and both heat cured and light cured acrylic were not significant despite the mean differences found, this is in agreement with Memarian and Shayestehmajd ${ }^{(26)}$ who found that MMA alter the surface morphology without improving the shear bond strength, while the results disagree with Kulkarni and Parkhedkar ${ }^{(21)}$ and with Sarac et al (27) who found that surface treatment of acrylic denture base with monomer increase the bond to soft lining material, this disagreements may be due to the differences in methodology of surface treatment used and materials.

The altering of surface material when exposed to laser energy is due to ablation which is removing of surface material because of energy absorption, and since the material exposed in this study is polymer so a photochemical ablation took place creating ablated regions, carrying away liquid and solid clusters of material substrate ${ }^{(28)}$.

Regarding surface treatment with Nd-Yag laser, the second dose of laser had the highest mean value compared to first dose; this may be due to the different absorption capacity of resin material ${ }^{(29)}$. Also Suke et al ${ }^{(30)}$ explain a chemical change may occur on acrylic surface when exposed to laser energy which cause shortening of chain length then increasing the chain cross linking, and this is believed to ameliorate the bond between denture base material and soft lining material.

Laser energy cause more irregularities than methyl methacrylate monomer, this explains the high significant values compared to monomer and control groups; the rough surface creates a larger contact area in denture base and improve the micromechanical interlocking ${ }^{(31)}$ this will affect the bond strength of denture base with soft liner in a good way ${ }^{(32)}$. this comes in agreement with Jacobson et al ${ }^{(33)}$ who stated that soft lining material has the ability to penetrate to denture base irregularities which improve the adhesion, it also agrees with Al-Noori and Al-Kateb (34) who found that laser treatment is superior to monomer.

Although it is an in vitro study and does not mimic the in vivo conditions but still can give a possible estimation of clinical outcome.

\section{REFERENCES:}

1. Harrison A. Temporary soft lining material. British Dent J 1981; 151:419-422.

2. Thomas J, Emmer Jr, Emmer TJ, et al. Bond strength of permanent soft denture liners bonded to the denture base. J Prosth Dent 1995;74:595-601.

3. Abdulsahib AJ. Evaluation of the tensile bond strengths of heat cure acrylic and valplast with silicone self cure soft liner. J Bagh College Dentistry 2012; 24(2): 5-9.

4. Roula W, Noor F, Hussam M. Effect of surface treatment on tensile bond strength between soft liner and acrylic denture base and the effect of Peppsi solution on this bond with and without surface treatment. J Bagh College Dentistry 2011; 23(2): 17-21.

5. Gopal KV, Josyula B, Reddy NR, et al. Comparison and evaluation of tensile bond strength of two soft liners to the denture base resin with different surface texture: An in vitro study. J NTR Univ Health Sci 2014; 3(2): 102-106.

6. Hristov I, Pavlov B, Ivanova D, et al. A comparative study on the bonding strength between the denture base and the relining materials. J of IMAB 2006;12(2):28-29.

7. Akin $\mathrm{H}$, Tugut $\mathrm{F}$, Mutaf $\mathrm{B}$, et al. Investigation of bonding properties of denture bases to silicone-based soft denture liner immersed in isobutyl methacrylate and 2-hydroxyethyl methacrylate. J Adv Prosthodont 2014;6:121-5.

8. Misuriya A, Gupta M. A comparative evaluation of shear bond strength of the fifth-generation bonding agent treated with neodymium-doped yttrium aluminum garnet laser before and after polymerization: An in vitro study .Journal of Dental Lasers $2014 ; 8(2): 40-43$.

9. Viraparia P, White JM, Vaderhobli RM. In: CO2 Laser Optimisation and Application, (D.C. Dumitras, editor) InTech, Rijeka (Croatia)-New York-Shanghai (2012)

10. Use of Lasers in Dentistry. AAE Position Statement on Use Lasers in Dentistry 2012 www.aae.org/guidelines.

11. A Brief History of Lasers. kigre.com/files/historylasers.pdf , p1-8.

12. Malkoç MA, Demir N, Ögreten AT, et al. Effect of new laser type on shear bond strength of acrylic teeth to denture base. J Res Dent 2015;3(1):26-30.

13. Al- Azzawi RW. Evaluation of Some Properties of Three Types of Denture Reline Materials with Miconazole (Antifungal agent) Preparation. A thesis College of Dentistry at the University of Baghdad .2007

14. Barbosa DB, Monterio DR, Barao VA, et al. Effect of monomer treatment and polymerization methods on the bond strength of resin teeth to denture base material. J 
Gerodontology 2009; 26(3):225-31.

15. Hatim NA, Hassan RH. Bond strength of different artificial tooth manufacturing to microwave cured acrylic denture base. AL-Rafidain Dent J 2010;10(1):8-16

16. Rasheed SK. The Effect of Er:YAG laser surface treatment on shear bond strength and some mechanical properties of heat cure acrylic denture base material bonded to chair side soft lining material. A thesis College of Dentistry, University of Baghdad 2014.

17. Yousif AA. The effect of disinfection, tray perforation and adhesive usage on the tensile and shear bond strength using two different elastomeric impression materials, (comparative study). A thesis college of dentistry, University of Baghdad, 2006.

18. Salloum AM. Shear bond strength of three silicone lining materials bonded to heat-cured denture resin. King Saud University Journal of Dental Sciences 2013; 4: 17-20

19. Astm. Specification ,D-638m, 1986.

20. Dootz ER, Koran A. and Craig RG. Physical property comparison of 11 soft denture lining materials as a function of accelerated aging. J Prosth Dent 1993;69:114-119.

21. Kulkarni RS, Parkhedkar R. The effect of denture base surface pretreatments on bond strengths of two long term resilient liners. J Adv Prosth 2011;3:16-19.

22. Fowler JA. A comparison of bonding strength characteristics between a silicone rubber, Silastic 390, and various denture base resins. in: MScD thesis. University of Texas, ; 1968. Cited in Al-Athel MS, Jagger RG, Jerolimov V. Bone strength of resilient lining materials to various denture base resins. Int J Prosthodont 1996;9:167-70.

23. Cantor R, Webber RL, Stroud, L, Ryge, G. Methods for evaluating prosthetic facial materials. J Prosthet Dent. 1969;21:324-332. Cited in Al-Athel MS, Jagger RG, Jerolimov V. Bone strength of resilient lining materials to various denture base resins. Int J Prosthodont 1996;9:16770 .
24. Chaladek G, Zmudzki J, Kasperski J. Long- term soft denture lining materials. Materials 2014;7:5816-5842.

25. Shihab RA., Hussein BM. Effect of certain chemical surface treatments on repair bond strength of some denture base materials. J Bagh College Dentistry 2014; 26(1): 53-8.

26. Jacobsen NL, Mitchell DL, Johnson DL, Holt RA. Lased and sandblasted denture base surface preparations affecting resilient liner bonding. J Prosthet Dent 1997;78:153-8.

27. Sarac D, Sarac YS, Basoglu T, et al. The evaluation of microleakage and bond strength of a silicone-based resilient liner following denture base surface pretreatment. J Prosthet Dent 2006;95:143-51.

28. Korkmaz FM, Bagis B, Ozcan M, et al. Peel strength of denture liner to PMMA and polyamide: laser versus airabrasion. J Adv Prosthodont. 2013; 5: 287-295.

29. Sugioka K, Meander M, Pique A. Laser Precision Microfabrication, Springer Series in Materials Science 135, DOI 10.1007/978-3-642-10523-4-4, c Springer-Verlag Berlin Heidelberg 2010:100.

30. Suke E, Scharf T, Scharf P, et al. Variation of the mechanical properties of pulsed laser deposited PMMA films during annealing. Applied Phys. A 2004;97:1295-1297.

31. Bragaglia LE, Maykot LH, Calvo MC. The role of surface treatments on the bond between acrylic denture base and teeth. Braz Dent J 2009;20(2): 156-161.

32. Sakaguchi RL, Powers JM. Restorative dental materials. Thirteenth edition 2012:192.

33. Memarian M, Shayestehmajd M. The effect of chemical and mechanical treatment of the denture base resin surface on the shear bond strength of denture repairs. Rev Clín Pesq Odontol $2009 ; 5(1): 11-17$

34. Al-Noori AK, Al-Kateb HM. Evaluation of microleakage of soft liners to highly impact acrylic resin. Al-Rafidain Dent J2012; 12(2):378-385. 